\title{
EVALUASI ANTARA PEMBERIAN ASI SECARA EKSKLUSIF DAN PEMBERIAN SUSU FORMULA PADA BAYI 0-6 BULAN DENGAN PERCEPATAN PERTUMBUHAN GIGI PERTAMA KALI PADA BAYI USIA 6-12 BULAN DI UPTD PUSKESMAS KECAMATAN PONTIANAK KOTA TAHUN 2017
}

\author{
Windiyati $^{1}$, S. Arismawati ${ }^{2}$
}

\author{
Akademi Kebidanan Panca Bhakti Pontianak
}

Email korespondensi: akbidpbpontianak@gmail.com

\begin{abstract}
Abstrak
Menurut WHO hanya 36\% dari bayi usia 0-6 bulan diseluruh dunia yang mendapatkan ASI eklusif periode 2007 2014. Berdasarkan laporan tumbuh kembang balita di UPTD Puskesmas Kec. Pontianak Kota tahun 2017, kasus perlambatan tumbuh gigi adalah $67,5 \%$. Hal ini sesuai dengan teori Purnamawati (2005) umumnya gigi tumbuh pada usia 4-7 bulan. Dan teori Ade Benih (2014) nutrisi yang cukup akan mempengaruhi percepatan pertumbuhan gigi bayi. Oleh karena itu judul penelitian ini adalah evaluasi antara pemberian ASI secara eklusif dan susu formula terhadap percepatan pertumbuhan gigi pada bayi. Penelitian ini bertujuan untuk mengetahui hasil evaluasi antara pemberian ASI secara eklusif dan susu formula dengan percepatan pertumbuhan gigi pertama kali pada bayi usia 6-12 bulan di UPTD Puskesmas Kec. Pontianak Kota tahun 2017. Desain penelitian ini menggunakan survey analitik dengan pendekatan cros sectional. Populasi sebanyak 135 bayi dan jumlah sampel 34 bayi dengan tehnik sampling kuota. Instrument penelitian yaitu kuisioner dan observasi. Variabel penelitian meliputi pemberian ASI secara eklusif dan susu formula dan percepatan pertumbuhan gigi pertama kali pada bayi usia 6-12 bulan. Data dianalisis dengan univariat dan bivariat menggunakan uji statistik wilcoxon match pairs test dengan tingkat kepercayaan $95 \%$. Hasil penelitian bayi yang diberi ASI secara eklusif sebagian besar mengalami percepatan pertumbuhan gigi yaitu sebanyak 14 responden $(82,4 \%)$. Dan bayi yang diberi susu formula sebagian mengalami perlambatan pertumbuhan gigi yaitu sejumlah 10 responden $(58,9 \%)$. Didapatkan nilai $\mathrm{p}=0,00<$ alpha $(0,05)$ artinya ada hubungan dan perbedaan yang signifikan percepatan pertumbuhan gigi pada bayi yang diberi ASI secara eklusif dan diberi susu formula. Kesimpulan dari penelitian ini adalah ada hubungan antara pemberian ASI secara eklusif dan pemberian susu formula dengan percepatan pertumbuhan gigi $(\mathrm{p}=0,00<$ alpha $5 \%(0,05)$. Oleh karena itu disarankan pemberian konseling tentang ASI eklusif dapat lebih di tingkatkan kepada ibu hamil.
\end{abstract}

Kata Kunci: ASI Eksklusif, Susu Formula, Pertumbuhan Gigi

\section{Pendahuluan}

Air susu ibu (ASI) adalah suatu emulasi lemak dalam larutan protein, laktose dan garam organik yang disekresi oleh kedua belah kelenjar payudara ibu, sebagai makanan utama bayi (Weni, 2009). ASI adalah susu yang diproduksi seorang ibu untuk di konsumsi bayi dan merupakan sumber gizi utama bayi yang belum bisa mencerna makanan padat. ASI di produksi di dalam alveoli karena pengaruh hormon prolaktin dan oxytocin setelah kelahiran bayi. ASI tersebut dapat mengalir masuk akibat kerja otot-otot halus yang mengelilingi alveoli. Air susu kemudian

\footnotetext{
${ }^{1}$ Dosen Akademi Kebidanan Panca Bhakti Pontianak

${ }^{2}$ Dosen Akademi Kebidanan Panca Bhakti Pontianak
}

mengalir ke saluran yang lebih besar yang selanjutnya masuk ke dalam jaringan penyimpanan air susu yang terletak tepat dibawah aerola. Jaringan ini berfungsi seperti bak penampungan air susu sementara, sampai saatnya daya hisapan melalui celah pada puting susu (Ade Benih, 2014).

Pemberian ASI secara eklusif menurut Peraturan Pemerintah Republik Indonesia, nomor 33 tahun 2012 adalah ASI yang diberikan pada bayi sejak dilahirkan selama 6 (enam) bulan, tanpa menambahkan atau mengganti dengan makanan atau minuman lain 
(kecuali obat, vitamin, dan mineral). Setiap ibu yang melahirkan harus memberikan ASI secara eklusif kepada bayi yang dilahirkan. Menurut Weni (2009) ASI eklusif adalah bayi yang hanya diberi ASI saja selama 6 bulan, tanpa tambahan cairan lain seperti susu formula, jeruk, madu, air teh dan air putih serta tanpa tambahan makanan padat seperti pisang, bubur susu, biskuit, bubur nasi, dan nasi tim.

Sedangkan susu formula adalah susu yang berasal dari hewan (sapi, kambing, domba) yang nutrisinya diserupakan dengan kandungan air susu ibu (ASI). Susu formula merupakan cairan atau bubuk dengan formula tertentu, diberikan pada bayi dan anak-anak yang berfungsi sebagai pengganti ASI. Susu formula memiliki peranan yang sangat penting dalam makanan bayi karena sering kali bertindak sebagai satu- satunya sumber gizi bagi bayi (Ronald, 2011).

Bahan dasar susu formula adalah susu sapi yang telah dimodifikasi dan diformulasi sedemikian rupa agar memberikan keseimbangan zat gizi bagi bayi yaitu mengandung zat-zat yang terdapat dalam ASI. Tetapi setelah melalui proses modifikasi zat-zat yang ada di dalam susu formula berkurang atau menyusut (Sara Lewis, 2004). Susu formula bukan pengganti makanan, melainkan hanya melengkapi. Jadi pemberian susu formula belum memenuhi kebutuhan gizi bayi. Bayi tidak perlu di berikan susu formula sebelum menjelang penyapihan (Nurhaeni, 2009).

Pengganti air susu ibu (PASI) diantaranya berbagai produk formula komplit yang komposisinya mendekati ASI, kecuali dalam hal komposisi mineral dan imunoglobulin. Jika keseimbangan gizi dan mineral tidak terpenuhi maka pertumbuhan mekanisme perlindungan alami terganggu, potensi tumbuh kembang tidak optimal (Atikah, Eni, 2010).

Pemberian makanan utama pada bayi sangat menentukan pada proses pertumbuhan dan perkembangan. Istilah tumbuh kembang sebenarnya mencangkup 2 peristiwa yang sifatnya berbeda, tapi sering berkaitan dan sulit dipisahkan, yaitu pertumbuhan dan perkembangan. Pertumbuhan (growth) berkaitan dengan masalah perubahan dalam besar jumlah, ukuran atau dimensi tingkat sel, organ maupun individu, yang bisa diukur dengan ukuran berat (gram, pound, kilogram), ukuran panjang (cm, meter), umur tulang dan keseimbangan metabolik (retensi kalsium dan nitrogen tubuh) (Hanum, 2010).

Ciri pertumbuhan anak meliputi pertambahan material, baik terkait pertumbuhan yang bersifat kuantitatif dan kualitatif, asalkan tidak berhubungan dengan fungsinya. Mengacu pada pengertian pertumbuhan anak, dapat ditentukan ciri-ciri yang menunjukan pertumbuhan anak, yakni bertambah berat badan, tinggi badan, lingkar kepala, tumbuh dan tanggalnya gigi, serta perubahan tubuh lainnya (Fida, Maya, 2012).

Penelitian yang dilakukan oleh Yandi Locitasari (2015). Untuk membandingkan perbedaan pertumbuhan bayi usia $0-6$ bulan secara umum yang diberi ASI secara eklusif dengan yang diberi susu formula di Kecamatan Ngawi. Penelitian yang dilakukan terhadap 42 
responden diketahui bahwa bayi dengan pertumbuhan baik yang diberi ASI secara eklusif berjumlah 18 orang $(85,7 \%)$ dan yang diberi susu formula berjumlah 11 orang $(52,4 \%)$, sedangkan bayi dengan pertumbuhan buruk yang diberi ASI secara eklusif berjumlah 3 orang $(14,3 \%)$ dan yang diberi susu formula berjumlah 10 orang $(47,6 \%)$. Dari hasil penelitian menunjukan pertumbuhan bayi yang diberi ASI secara eklusif lebih baik dari pada diberi susu formula. (Yandi Locitasari, 2015).

\section{Menurut World Health Organization} (WHO) setiap bayi dan anak berhak untuk mendapatkan nutrisi yang baik sesuai dengan konvensi hak-hak anak. Secara global hanya $36 \%$ dari bayi usia 0-6 bulan yang mendapatkan ASI secara eklusif. Analisis menunjukan bahwa banyak bayi dan anak-anak tidak menerima makanan secara optimal. Misalnya hanya sekitar 36\% dari bayi usia 0-6 bulan diseluruh dunia mendapatkan ASI secara eklusif selama periode 2007-2014.

World Health Organization (WHO) dan The United Nations Children's Fund (UNICEF) merekomendasikan pola pemberian makanan terbaik bagi bayi dan anak sampai usia dua tahun. Rekomendasi tersebut antara lain memberikan ASI secara eklusif sejak lahir sampai usia enam bulan, memberi makanan pendamping ASI sejak bayi berusia dua tahun atau lebih, menetapkan kebijakan tentang pemberian nutrisi bagi bayi. Semua negara didunia sangat diharapkan dapat mengimplementasikan rekomendasi tersebut sesuai dengan kondisi masing-masing negara dalam rangka mencapai derajat kesehatan anak yang optimal (Ika Murtiyarini dkk, 2014).

Menurut data survey Dinas Kesehatan Kota Pontianak tahun 2015 jumlah bayi yang ada diwilayah Kota Pontianak adalah sekitar 12.050 bayi, jumlah bayi yang berusia $0-6$ bulan yaitu sebanyak 5.288. Menurut jenis kelamin 2.648 jiwa laki-laki dan 2.640 jiwa perempuan. Dari 5.288, bayi usia 0-6 bulan yang ada di Kota Pontianak, berjumlah 2.155 bayi yang diberi ASI secara eklusif dan 3.133 bayi yang di beri ASI secara non-eklusif. Kemudian jumlah bayi yang berusia 6-12 bulan yang berkunjung ke UPTD Puskesmas Kecamatan Pontianak Kota tahun 2015 berkisar 232 bayi. Dari 232 bayi, 85 diantaranya diberi ASI secara eklusif dan 147 bayi yang susu formula saja.

Berdasarkan buku laporan tumbuh kembang balita di ruang Kesehatan Ibu dan Anak (KIA) UPTD Puskesmas Kecamatan Pontianak Kota pada tahun 2016, kasus perlambatan tumbuh gigi pada balita yakni gigi tumbuh pada usia lebih dari 7 bulan adalah $67,5 \%$. Dan balita yang mengalami tumbuh gigi pada usia 4-7 bulan sejumlah $32,5 \%$. Hal ini menunjukan masih banyaknya balita yang mengalami perlambatan pertumbuhan gigi yang menurut laporan tumbuh kembang anak disebabkan oleh asupan yang diberikan kepada anak selama usia $0-12$ bulan.

Kandungan nutrisi penting untuk seluruh proses metabolisme di dalam tubuh. Pemilihan jenis makanan sepanjang kehidupan akan menentukan status pertumbuhan dan perkembangan gigi dan tulang, terutama makanan dengan tinggi protein dan kalsium. 
Makanan dengan kualitas dan konsentrasi protein dan kalsium yang tinggi mempunyai hubungan linier dengan pertumbuhan dan perkembangan tulang dan gigi. Hal ini disebabkan protein merupakan makanan yang mengandung banyak asam amino sebagai unsur pembangun struktur jaringan tubuh, sedangkan kalsium merupakan mineral penting yang berperan dalam seluruh proses metabolisme tulang dan gigi.

Keterlambatan pertumbuhan dan perkembangan tulang dan gigi serta kelainan tulang dan gigi penduduk Indonesia cukup tinggi, kejadian ini dihubungkan dengan daya konsumsi makanan tinggi protein dan kalsium penduduk Indonesia masih cukup rendah (Aryati, Dharmayanti, 2014). Benih gigi mulai dibentuk sejak janin berusia 7 minggu dan berasal dari lapisan ektodermal serta mesodermal. Lapisan eksodermal berfungsi untuk membentuk email dan odontoblas, sedangkan mesodermal membentuk dentil pulpa, sementum. Membran periodontal, dan tulang alveolar (Amandia, Sulistiyani, 2010).

Penelitian yang dilakukan oleh Naora Atika dkk (2014). Untuk membandingkan perbedaan pemberian ASI secara eklusif dan susu formula terhadap pertumbuhan bayi umur 7-12 bulan di Desa Reksosari Kec. Suruh Kab. Semarang. Penelitian yang dilakukan terhadap 34 bayi dari hasil penelitian di dapatkan dari 17 bayi yang diberikan ASI secara eklusif ada 15 bayi $(88,2 \%)$ memiliki pertumbuhan baik dan 2 bayi $(11,8 \%)$ memiliki pertumbuhan kurang. Sedangkan dari 17 bayi yang diberikan susu formula, 4 bayi $(23,5 \%)$ memiliki pertumbuhan baik dan 13 bayi $(76,5 \%)$ memiliki pertumbuhan kurang. Maka dapat disimpulkan ada perbedaan yang signifikan pemberian ASI secara eklusif dan susu formula terhadap status pertumbuhan bayi umur 7-12 bulan yang meliputi tinggi badan, berat badan, ukur lingkar kepala, ukur lingkar lengan atas dan tumbuh gigi di Desa Reksosari Kec. Suruh Kab. Semarang (Naora Atika, 2014).

Nutrisi yang cukup memenuhi kebutuhan bayi akan mempengaruhi percepatan pertumbuhan bayi sesuai usia, bentuk pertumbuhan bayi usia 6-12 bulan salah satunya adalah pertumbuhan gigi. Serta proses menyusui membuat otot-otot rahang dan wajah berperan ketika bayi menghisap puting ibu yang dapat merangsang pertumbuhan gigi. Demikian bayi yang mendapat ASI secara eklusif akan mengalami lebih cepat tumbuh gigi dibandingkan dengan bayi yang mendapat susu formula (Ade Benih, 2014).

Penelitian oleh Edi Sutrisno (2014), tentang hubungan pemberian dot dengan pertumbuhan gusi dan gigi pada bayi $6-24$ bulan di desa Gayaman Mojokerto. Hasil uji chi square di dapatkan nilai $p$-value $=0,001<$ alpha $(0,05)$. Menunjukan ada hubungan yang bermakna antara pemberian dot dengan pertumbuhan gusi dan gigi bayi. Serta dipertegas dengan hasil penelitian Naomi dkk (2015), tentang hubungan pemberian ASI eklusif dengan kesehatan mulut dan pertumbuhan gigi pada bayi 6-12 bulan di desa Waru Jawa Timur. Hasil uji chi square di dapatkan nilai $p$-value $=0,00<$ alpha $(0,05)$. Menunjukan ada hubungan yang signifikan 
antara pemberian ASI eklusif dengan kesehatan mulut dan pertumbuhan gigi.

Berdasarkan hasil studi pendahuluan, yang peneliti lakukan pada tanggal 02 februari 2017 di ruang gizi UPTD Puskesmas Kecamatan Pontianak Kota kepada 10 bayi yang mendapat ASI secara eklusif dan 10 bayi yang mendapat susu formula saja. Peneliti melakukan wawancara kepada ibu bayi didapatkan hasil 9 dari 10 bayi yang mendapat ASI secara eklusif mengalami pertumbuhan gigi pada usia 5-7 bulan, dan 1 bayi lainnya mengalami pertumbuhan gigi pada usia 11 bulan. Sedangkan 1 diantara 10 bayi yang diberi susu formula mengalami pertumbuhan gigi pada usia 6 bulan, 3 bayi mengalami pertumbuhan gigi pada usia 8-10 bulan dan 6 bayi lainnya belum tumbuh gigi.

\section{Metode}

Penelitian ini menggunakan jenis penelitian deskriptif korelasional dengan pendekatan cross sectional. Penelitian dilaksanakan pada bulan Januari hingga Mei 2017 di UPTD Puskesmas Kecamatan Pontianak. Populasi penelitian yaitu bayi usia 612 bulan yang diberi ASI secara eksklusif sebanyak 68 bayi dan diberi susu formula sebanyak 79 bayi. Peneliti menggunakan 15\% dari populasi menjadi sampel sebanyak 34 bayi. Pengumpulan data menggunakan kuesioner kemudian diolah dan dianalisis menggunakan analisis univariat serta analisis bivariat menggunakan uji Wilcoxon match pairs test.

\section{Hasil dan Pembahasan}

Tabel 1. Karakteristik Responden

\begin{tabular}{lccccc}
\hline \multicolumn{1}{c}{ Karakteristik } & \multicolumn{2}{c}{ ASI Eksklusif } & \multicolumn{2}{c}{ Susu Formula } \\
& $\mathrm{n}$ & $\%$ & \multicolumn{2}{c}{$\mathrm{n}$} & $\%$ \\
\hline Pertumbuhan Gigi & & & & \\
Cepat $(4-7$ bulan) & 14 & 82,4 & 7 & 41,1 \\
Lambat $(>7$ bulan) & 3 & 17,6 & 10 & 58,9 \\
\hline
\end{tabular}

Berdasarkan tabel 1 diketahui perbedaan antara percepatan pertumbuhan gigi bayi pertama kali. Hampir seluruh responden yang diberi ASI secara eklusif mengalami pertumbuhan gigi pada usia 4-7 bulan sebanyak 14 responden
$(82,4 \%)$ dan bayi yang diberi susu formula sebagian mengalami pertumbuhan gigi pertama kali pada usia $>7$ bulan yaitu 10 responden $(58,9 \%)$

Tabel 2. Dirstribusi Rata-Rata Percepatan Pertumbuhan Gigi Bayi Pertama Kali yang diberi ASI Eksklusi dan diberi Susu Formula

\begin{tabular}{|c|c|c|c|c|c|}
\hline Kategori & Mean & $\begin{array}{l}\text { Standar } \\
\text { Deviasi }\end{array}$ & $\begin{array}{c}\text { Standar } \\
\text { Error Mean }\end{array}$ & P value & $\mathrm{N}$ \\
\hline $\begin{array}{l}\text { ASI Eksklusif \& Percepatan } \\
\text { Tumbuh Gigi }\end{array}$ & -5.535 & 1.367 & .331 & 0,000 & 17 \\
\hline $\begin{array}{l}\text { Susu Formula \& Percepatan } \\
\text { Tumbuh Gigi }\end{array}$ & -8.588 & 1.906 & .462 & 0,000 & 17 \\
\hline
\end{tabular}


Berdasarkan tabel 2 diketahui rata-rata pertumbuhan gigi bayi yang diberi ASI secara eklusif adalah 5,3 bulan dengan standar deviasi 1,367 bulan, sedangkan pertumbuhan gigi pada bayi yang diberi susu formula 8,5 bulan dengan standar deviasi 1,906 bulan. Hasil uji statistik didapatkan nilai $\mathrm{p}=0,00<$ alpha $5 \%(0,05)$ terlihat ada perbedaan yang signifikan percepatan pertumbuhan gigi pada bayi usia 612 bulan yang mendapat ASI secara eklusif dan yang mendapat susu formula saat usia 0-6 bulan.

Pertumbuhan gigi bayi yang diberi ASI secara eklusif, berdasarkan hasil penelitian yang dilakukan hampir seluruh responden yang diberi ASI secara eklusif mengalami percepatan pertumbuhan gigi yaitu pada saat usia 4-7 bulan, sebanyak 14 responden $(82,4 \%)$. Dan yang mengalami perlambatan pertumbuhan gigi yaitu pada saat usia $>7$ bulan sejumlah 3 orang $(17,6 \%)$.

Hal ini didukung oleh teori dari Jane (2003) yang menyatakan tidak perlu melakukan hal khusus untuk membantu gigi bayi tumbuh dengan baik, selain merawat dan menyantap makanan dengan gizi seimbang. Namun beberapa peristiwa yang dapat berdampak langsung pada pertumbuhan gigi diantaranya adalah asupan nutrisi ibu selama hamil, infeksi atau terpapar virus atau bakteri, serta obatobatan yang dapat menggangu perkembangan benih gigi bayi.

Diperkuat oleh Purnamawati (2005) bahwa setiap gigi berbeda-beda secara anatomi, tapi dasar proses pertumbuhannya sama. Gigi sudah mulai terbentuk (dibawah gusi) saat bayi masih di dalam kandungan. Usia saat pertama gigi anak keluar dari gusi sangat bervariasi. Namun yang paling umum gigi muncul pada usia 4-7 bulan. Dan sesuai dengan hasil penelitian Naora dkk (2014) tentang perbedaan pemberian ASI secara eklusif dan susu formula terhadap pertumbuhan bayi umur 7-12 bulan. Membuktikan pertumbuhan gigi bayi yang diberi ASI secara eklusif lebih cepat $(88,2 \%)$ di bandingkan dengan bayi yang diberi susu formula $(23,5 \%)$ di Desa Reksosari Kec. Suruh Kab. Semarang.

Sedangkan pertumbuhan gigi bayi yang diberi susu formula, berdasarkan hasil penelitian yang dilakukan, sebagian dari responden yang diberi susu formula mengalami perlambatan pertumbuhan gigi yaitu pada saat usia $>7$ bulan berjumlah 10 responden $(58,9 \%)$. Dan yang mengalami percepatan pertumbuhan gigi yaitu pada saat usia 4-7 bulan berjumlah 7 responden $(41,1 \%)$.

Hal ini sesuai pendapat dari Nurhaeni Arif (2009) mengatakan susu formula tidak dapat mengoptimalkan pertumbuhan bayi akibat proses pengenceran dengan konsentrasi tertentu yang tidak sesuai dengan kemampuan daya serap saluran cerna bayi. Jika terlalu encer, dapat menyebabkan kekurangan gizi sehingga pertumbuhannya terhambat, dan pertumbuhan gigi menjadi lambat. Sebaliknya jika pengencerannya terlalu pekat dapat memicu terjadinya obesitas (kegemukan) dan karies gigi pada bayi dikemudian hari.

Didukung oleh penelitian Yandi Locitasari (2015) membandingkan perbedaan pertumbuhan bayi usia 0-6 bulan secara umum 
yang diberi ASI secara eklusif dengan yang diberi susu formula di Kecamatan Ngawi. Hasil penelitian menunjukan pertumbuhan bayi yang diberi susu formula sebagian mengalami pertumbuhan yang buruk $(52,4 \%)$.

Berdasarkan hasil penelitian yang dilakukan diketahui rata-rata pertumbuhan gigi bayi yang diberi ASI secara eklusif adalah 5,3 bulan dengan standar deviasi 1,367 bulan, sedangkan pertumbuhan gigi pada bayi yang diberi susu formula 8,5 bulan dengan standar deviasi 1,906 bulan. Hasil uji statistik didapatkan nilai $\mathrm{p}=0,00<$ alpha $5 \%(0,05)$ terlihat ada perbedaan yang signifikan percepatan pertumbuhan gigi pada bayi usia 612 bulan yang mendapat ASI secara eklusif dan yang mendapat susu formula saat usia 0-6 bulan.

Hal tersebut sesuai pendapat Ade Benih (2014) bahwa Ibu menyusui bisa memproduksi susu diperuntukkan khusus untuk bayi. Dan juga merupakan susu yang telah bervolusi untuk bisa menyesuaikan pertumbuhan dan perkembangan bayi. Sedangkan susu formula yang berasal dari mamalia tentu tidak sama dengan pemberian ASI kepada bayinya, yang mendasari perbedaan pertumbuhan gigi antara pemberian ASI secara eklusif dan susu formula adalah pada nutrisi yang di kandungnya. Nutrisi yang cukup memenuhi kebutuhan bayi akan mempengaruhi percepatan pertumbuhan bayi sesuai usia, bentuk pertumbuhan bayi usia 6-12 bulan salah satunya adalah pertumbuhan gigi.

Diperkuat oleh teori Jane (2003) bahwa, hal lain yang mendasari pertumbuhan gigi adalah yang dilakukan bayi ketika minum, baik dari botol maupun payudara, membantu rahang nya untuk menumbuhkan dan mengembangkan otot-otot pipi yang dibutuhkan untuk mengunyah dan berbicara. Serta pendapat Ade Benih (2014) menyebutkan dari proses tersebut otot-otot rahang dan wajah berperan ketika bayi menghisap puting ibu yang dapat merangsang pertumbuhan gigi.

Sejalan dengan hasil penelitian Edi Sutrisno (2014), tentang hubungan pemberian dot dengan pertumbuhan gusi dan gigi pada bayi 6 - 24 bulan di desa Gayaman Mojokerto. Hasil uji chi square di dapatkan nilai $p$-value $=$ $0,001<$ alpha (0,05). Menunjukan ada hubungan yang bermakna antara pemberian dot dengan pertumbuhan gusi dan gigi bayi.

Serta dipertegas dengan hasil penelitian Naomi dkk (2015), tentang hubungan pemberian ASI eklusif dengan kesehatan mulut dan pertumbuhan gigi pada bayi 6-12 bulan di desa Waru Jawa Timur. Hasil uji chi square di dapatkan nilai $p$-value $=0,00<$ alpha $(0,05)$. Menunjukan ada hubungan yang signifikan antara pemberian ASI eklusif dengan kesehatan mulut dan pertumbuhan gigi.

\section{Kesimpulan}

Kesimpulan dari penelitian ini adalah ada hubungan antara pemberian ASI secara eklusif dan pemberian susu formula dengan percepatan pertumbuhan gigi $(\mathrm{p}=0,00<$ alpha $5 \%(0,05)$. Oleh karena itu disarankan pemberian konseling tentang ASI eklusif dapat lebih di tingkatkan kepada ibu hamil. 


\section{Daftar Pustaka}

Amandia, Sulistiyani. 2010. Pertumbuhan Erupsi Gigi Anak. http://jurnal.unej.ac.id/index.php/STOM A/article/download/2074/1678\&ved diakses 15.03.2017 pukul: 11.00 WIB

Arif, Nurhaeni. 2009. Panduan Ibu Cerdas Asi Dan Tumbuh Kembang Bayi. Jakarta: PT. Buku Kita

Arikunto, Suharsimi. 2006. Prosedur Penelitian Suatu Pendekatan Praktik. Jakarta: Rineka Cipta

Aryati, Dharmayanti. 2015. Manfaat Ikan Teri Segar (Stolephorus Sp) Terhadap Pertumbuhan Tulang Dan Gigi Odonto Dental Journal. Volume 1 Nomor 2. Http://Jurnalkesmas.Ui.Ac.Id/Index.P hp/Odj/Issue/View/62, diakses : 17 Maret 2017, 10.50 WIB di Kota Pontianak

Atika, Naora 2014. Perbedaan Pemberian Asi Eklusif Dan Susu Formula Terhadap Status Gizi Bayi Umur 7-12 Bulan Di Desa Reksosari

Bowden, Jane \& Manning, Vicky. 2012. Promosi Kesehatan Dalam Kebidanan: Prinsip Dan Praktek,Ed.2. Jakarta: Buku Kedokteran EGC

Chumbley, Jane \& Walters Clare. 2003. Merawat Gigi Bayi Cara Menjaga Kesehatan Gigi Dan Gusi Anak. Jakarta: Erlangga

Fida \& Maya. 2012. Pengantar Ilmu Kesehatan Anak. Yogyakarta: D-Medika

Fikawati, Sandra Dkk. 2015. Gizi Ibu Dan Bayi. Jakarta: Rajawali Pers

H.S, Ronald. 2011. Pedoman Perawatan Balita. Bandung: $\quad \mathrm{Cv}$ Nuansa Aulia http://www.dinkes.go.id/resources/down load/pusdatin/profil-kesehatanindonesia/profil-kesehatankotapontianak-2015.pdf, diakses : 07 Maret 2017, 09.10 WIB di Kota Pontianak
Imron, Moch \& Munif, Amrul. 2010. Metodelogi Penelitian Bidang Kesehatan Bahan Ajar Untuk Mahasiswa. Jakarta: CV Sagung Seto

Kristiyanasari, Weni. 2009. ASI, Menyusui \& Sadari. Yogyakarta: Nuha Medika

Lewis, Sara. 2004. Makanan Pertama Ku, Panduan Para Ibu Untuk Menyapih Dan Memperkenalkan Makanan Padat. Jakarta: Erlangga

Locitasari, Yandi. 2015. Perbedaan Pertumbuhan Bayi Usia 0-6 Bulan Yang Diberi Asi Eksklusif Dengan Yang Diberi Susu Formula Di Kec.Ngawi Https://Eprints.Ums.Ac.Id/39419/9/2.Na skah\%2520publikasi.Pdf\&Ved, Diakses: 26 Februari 2017, 09.44 Wib di Kota Pontianak

Marimbi, Hanum. 2010. Tumbuh Kembang, Status Gizi, Dan Imunisasi Dasar Pada Balita. Yogyakarta: Nuha Medika

Mubarok, Iqbal, Wahit Dkk. 2012. Promosi Kesehatan Sebuah Pengantar Proses Belajar Mengajar Dalam Pendidikan. Yogyakarta: Graha Ilmu

Murtiyarini, Ika Dkk. 2014. Evaluation Of Implementation Breastfeeding Counseling. Jurnal Kesehatan Masyarakat Nasional Vol. 9, No. 1, Http://Jurnalkesmas.Ui.Ac.Id/Kesmas /Article/View/460/0 , Diakses : 13 Maret 2017, 19.51 WIB di Kota Pontianak

Naomi dkk. 2015. Hubungan Pemberian ASI Eklusif Dengan Kesehatan Mulut Dan Pertumbuhan Gigi Pada Bayi 6-12 Bulan Di Desa Waru Jawa Timur. Https://Eprints.Uns.Ac.Id/32487/Pdf \&Ved, Diakses : 07 Mei 2017, 21.44 Wib di Kota Pontianak

Nirwana, Benih Ade. 2014. ASI Dan Susu Formula Kandungan Dan Manfaat ASI Dan Susu Formula. Yogyakrta: Nuha Medika

Notoatmodjo, Soekidjo. 2013. Promosi Kesehatan Teori Dan Aplikasi. Jakarta: Rineka Cipta 
Peraturan Pemerintah Republik Indonesia. 2012. Tentang Asi Eklusif. https://www.google.co.id/url?sa=t\&sour $\mathrm{ce}=\mathrm{web} \& \mathrm{rct}=\mathrm{j} \& u r \mathrm{l}=\mathrm{http}: / / \mathrm{www} \cdot$ kinerja. or.id/pdf/, diakses : 10 maret 2017, 15.18 WIB di Kota Pontianak

Proverawati, Atikah \& Rahmawati, Eni. 2010. Kapita Selekta Asi Dan Menyusui. Yogyakarta: Nuha Medika

Pujiarto S. Purnamawati. 2005. Seri Kesehatan Anak Bayiku Anakku Panduan Praktis Kesehatan Anak. Jakarta: PT. Intisari Mediatama

Ramaiah, Safitri. 2005. Manfaat Asi Dan Menyusui. Jakarta: PT. Bhuana Ilmu Populer

Sandjaja, B \& Heriyanto, Albertus. 2006. Panduan Penelitian. Jakarta: Prestasi Pustakaraya

Sugiyono. 2010. Statistika Untuk Penelitian. Bandung: IKAPI
2015. Statistik Non Parametris Untuk Penelitian. Bandung: Alfabeta Cv

Suryabudhi, Maria . 2001. Cara Merawat Bayi Dan Anak-Anak Buka Kedua. Bandung: Pionir Jaya

Sutrisno, Edi. 2014. Hubungan Pemberian Dot Dengan Pertumbuhan Gusi Dan Gigi Pada Bayi 6 - 24 Bulan Di Desa Gayaman Mojokerto.

Susila \& Suyanto. 2014. Metode Penelitian Epidemiologi Bidang Kedokteran Dan Kesehatan. Yogyakarta: Bursa Ilmu

Syafrudin Dkk. 2011. Untaian Materi Penyuluhan Kia (Kesehatan Ibu Dan Anak). Jakarta: CV. Trans Info Media

Warner, Penny. 2009. 365 Kiat Mengasuh Bayi Segala Sesuatu Yang Perlu Diketahui Pada Tahun Pertama. Jakarta : Arcan

www.who.int, diakses : 09 maret 2017, 13.45 WIB di Kota Pontianak. 